特集 4

腹膜再発予防を目的とした將膜露出胃癌症例に

\title{
対する制癌療法の検討
}

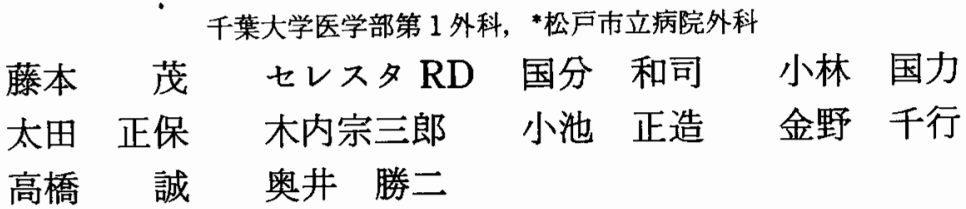

\section{PREVENTIVE ANTITUMOR TREATMENT FOR PERITONEAL RECURRENCE OF GASTRIC CANCER WITH SEROSAL INVASION}

\author{
Shigeru FUJIMOTO, Ram Dhoj SHRESTHA, Masashi KOKUBUN, \\ Kokuriki KOBAYASHI, Masayasu OHTA, Sohzaburo KIUCHI, \\ Shozo KOIKE, Chiyuki KONNO, Makoto TAKAHASHI* \\ and Katsuji OKUI
}

First Department of Surgery, School of Medicine, Chiba University Division of Surgery, Matsudo Municipal Hospital*

漿膜漫潤陽性胃癌症例の術後の腹膜再発を予防することを目的として, 腹腔内温熱灌流 (intraperitoneal hyperthermic perfusion；以下 IPHP）を行うとともに，腹腔内へ recombinant interleukin2 を投与した。対象胃癌18例は sel1例, sei 7 例であり, IPHPは $\mathrm{MMC} 10 \mu \mathrm{g} / \mathrm{ml}$ を含む灌流液の平均 流入温 $47.2^{\circ} \mathrm{C}$, 流出温 $45.1^{\circ} \mathrm{C}$ に保ち 120 分間行った. IPHP 直前に体表面冷却により $31 \sim 32^{\circ} \mathrm{C}$ 低体温 とし, 術中腹腔内癌細胞陽性14/18例 (77.8\%) は, IPHP 後に 1 例を除き陰性となった。術後第14病 日前後より recombinant interleukin-2 1000単位の腹腔内投与を14日間行い, 腹腔内浸出液中に NK 細胞を認めたので, 腹腔内局所に NK 活性の誘導が可能であり, 有効な局所免疫療法であることが示 唆された。

索引用語：墏膜露出胃癌, 腹腔内温熱灌流, Interleukin-2

\section{結言}

漿膜浸潤陽性胃癌症例の大半は腹腔内に遊離癌細胞 を認め, 術後比較的早期に腹膜播種として再発するこ とが多く，生存率を向上させるためにはこれの抑制を 計るべきである，著者らは腹膜播種あるいは漿膜漫潤 を有する胃癌症例に対して, 原発巣の根治手術直後に 低体温下に颃いて閉鎖回路に上る腹腔内温熱灌流 (intraperitoneal hyperthermic perfusion;以下

* 第32回日本消外会総会シンポ 1 ・漿膜露出胃癌治療 の工夫

$<1988$ 年10月12日受理 >別刷請求先：藤本 茂 ₹280 千葉市亥鼻 $1-8-1$ 千葉大学医学部第 1 外科
IPHP)を施行して顯著な制癌効果を挙げている11. 本 稿に打いてはIPHP後の腹腔内癌細胞の検討之, IPHP 後に施行している免疫学的な再発防止手段とし ての Interleukin-2（IL-2）の腹腔内投与について報告 するとともに, thermosensitization を目的として投与 している Ro 07-0582 (Misonidazole-MIS) に関する 知見を併せ報告する.

\section{研究方法}

漿膜侵襲陽性胃癌を有する男性 8 例，女性10例（平

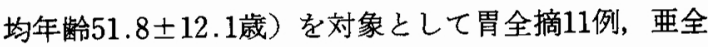
摘を 6 例，膵頭十二指腸切除を 1 例に行い，女性10例 中 6 例に卵巣転移を認めたので卵巣摘除を施行した。

これらの手術の後半より頭頸部周囲の水䧶と背部に 
図 1 腹腔内温熱灌流（IPHP）の模式図

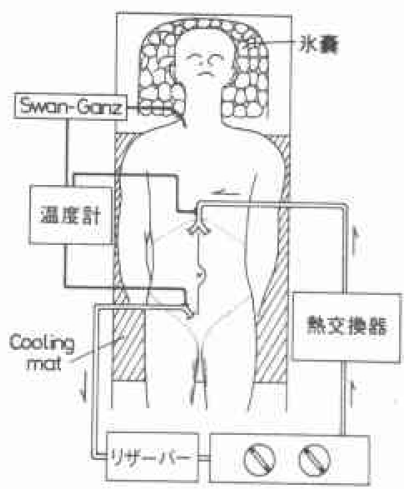

敷いた cooling matによる体表面冷却を行い, Swan Ganz catheter を介しての肺動脈温を，腹腔内の手術 操作が終了する前後までに31 32 $3{ }^{\circ} \mathrm{C}$ に低下させる，次 いで，腹壁を腹膜筋層の連続縫合により閉鎖した後 mitomycin C (MMC) $10 \mu \mathrm{g} / \mathrm{ml}$ を含む灌流液を流入 温 $47^{\circ} \mathrm{C}$ 前後に保ちつつ, IPHP 装置よりの流出温が $44^{\circ} \mathrm{C}$ 以上になってから120分間の IPHPを行った（図 1).また, thermosensitization を目的としてで MIS $1.4 \sim 1.8 \mathrm{~g} / \mathrm{m}^{2}$ IPHP 前 12,5 時間に 2 回投与した。 術後14日前後上り開始するIL-2の投与は，閉腹時に ダグラス窩に留置した triple lumen sump drainより, ヒト recombinant interleukin-2-rIL-2 (TGP-3) 1000 単位を 14 日間連続して注入した。

術中之術後における腹空内洗浄液あるいは浸出液の 細胞診は Papanicolaou と Giemsa 染色により行い, 末梢血と腹腔内浸出液中の natural killer (NK) 活性 は K-562細胞を標的細胞として測定した. MMC 濃度 は HPLC 法（測定限界 $0.002 \mu \mathrm{g} / \mathrm{ml}$ )により測定した。

\section{成 績}

\section{1. 抗腫瘍効果}

18例中14例 $(77.8 \%)$ 飞打いて術中の腹腔内洗浄液 中に癌細胞を認めたが (図 2), IPHP 後ダグラス简よ りの浸出液中には 1 例を除いて癌細胞は認められな かった。 図 3 は第 5 病日の腹腔内浸出液中の細胞群で あり, 顆粒球, 赤血球の間に癌細胞あるいは反応性中 皮細胞と考えられる細胞が認められる。この症例は手 術の 8 力月後に癌性胸水, 癌性腹水, 肝転移により死 亡した。

術前に超音波あるいは computed tomography (CT) Kより腹水を 6 例に認め, 全例腹水中癌細胞 が陽性であったが，IPHP 後は 6 例ともに腹水を認め
図 2 術中の腹腔内洗浄細胞診陽性例 (Papanicolaou 染色, $\times 100$ ).

細胞の集塊形成がほとんど認められない印環細胞型 癌細胞が主である。

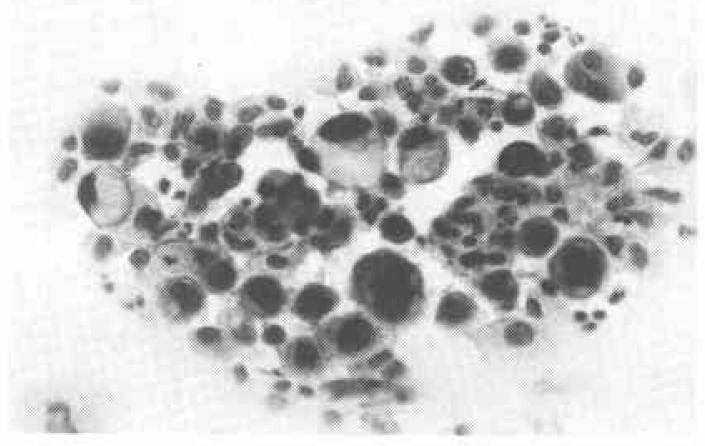

図 3 IPHP 終了 5 日後の腹腔内浸出液の細胞診 (Papanicolaou 染色, $\times 100$ ).

$15 \mu \mathrm{m}$ 前後の細胞が顆粒球に囲まれており, 癌細胞, 反応性中皮細胞, 大食細胞のいずれかの判定はむず かしい。

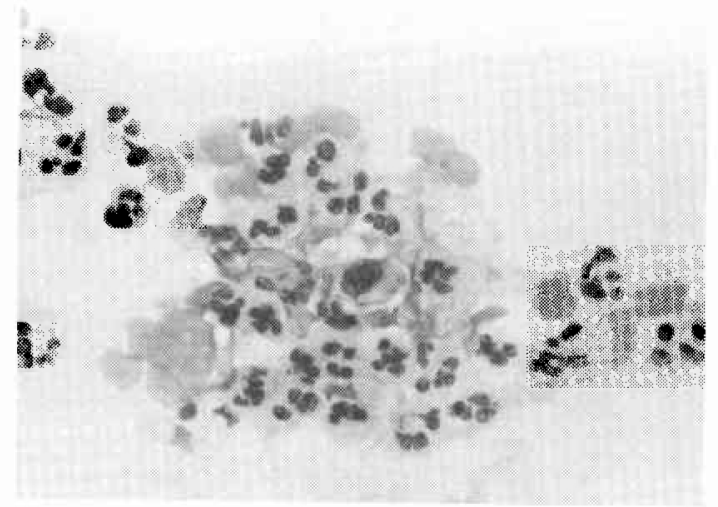

ず退院した．18例中 1 例は退院後交通事故死し，5例 は9.6土4.1月後に胃癌再発により死亡したが，12例は $11.5 \pm 8.3$ 月後の現在再発を認めず生存中である。

2. 灌流液と血中の薬剤濃度

IPHP 開始時の灌流液中 $\mathrm{MMC}$ 濃度は $10 \mu \mathrm{g} / \mathrm{ml}$ で あるが, 15 分前後で $5 \mu \mathrm{g} / \mathrm{ml}$, IPHP 終了時には1.7 $\mu \mathrm{g} /$ $\mathrm{ml}$ となり, 平均濃度は約 $3.3 \mu \mathrm{g} / \mathrm{ml}$ であった。一方, 血中 MMC 濃度は IPHP 開始 5 分後 $0.06 \mu \mathrm{g} / \mathrm{ml} 15$ 分 後には $0.11 \mu \mathrm{g} / \mathrm{ml}, 120$ 分後は $0.19 \mu \mathrm{g} / \mathrm{ml}$ に上昇し, 平 均濃度は約 $0.16 \mu \mathrm{g} / \mathrm{ml}$ であった。

3. Recombinant interleukin-2投与前後の免疫学的 
図 4 Recombinant interleukin-2 1000U/日14日間腹 腔内投与による末梢血中 $\mathrm{T}$ 細胞, $\mathrm{NK}$ 細胞, $\mathrm{T}$ 細胞 サブセットの变動

点線内は正常値の範囲を示す.
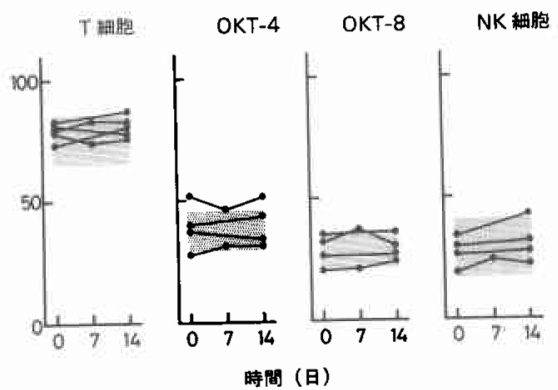

図 5 Recombinant interleukin-2 1000U/日の14日間 腹腔内投与による腹腔内浸出液中の $\mathrm{T}$ 細胞と $\mathrm{NK}$ 細胞

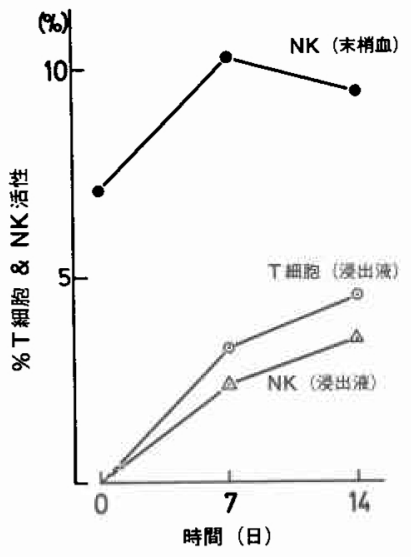

検討

r IL-2 $1000 \mathrm{U} /$ 日の投与前後に扣ける末梢血中の T 細胞, $\mathrm{T}$ 細胞サブセット, $\mathrm{NK}$ 細胞は有意の変動を示 さなかった（図 4)が，rIL-2の腹腔内投与により十分 な浸出液を回収しえた症例の浸出液中には， T 細胞と NK 細胞が5\%以下であるが存在した。その時の末梢血 中 NK 細胞約 $10 \%$ と低值を示したが，それに対して浸 出液中 NK 細胞は $3.5 \%$ と約 $1 / 3$ の値を示した（図 5 ）。

\section{4. 副作用}

白血球数は IPHP 後24時間, 48時間で 15000 以上に 増加したが，第 4 病日には術前値に復した。血小板は IPHP 後24時間に最低值を示し, 第 3 病日まで低值で あったが，第 4 病日には術前値に復した。肝機能とし ての血清 GOT, GPT は IPHP 終了 24 時間後に300U/ $\mathrm{ml}$ 前後に急増し, 以後漸減して第 $21 \sim 28$ 病日に正常值
に復した。

\section{考察}

IPHP は高温であるほど，また長時間であるほど制 癌効果が強まり, $45^{\circ} \mathrm{C}$ の場合は10 20分後には腫瘍組 織の毛細毛管内の血流停止が認められ3), これが制癌 効果の一因と考えられている. また，正常組織は $46^{\circ} \mathrm{C}$ 台では血流停止が認められない3ので，流入温を $47.0^{\circ} \mathrm{C}$ 前後とした。一方, 臨床応用に際しては全身麻 酔下にない患者では耐熱性が，全身麻酔下であっても 体温上昇による心肺脳機能に対する影響が重要であ り, 加温時間の問題は以下に述べる低体温麻酔に直接 関係している、腹腔における腹膜と漿膜の表面積は体 表面積以上であるので，癌細胞に十分な殺細胞作用を 与兄らる温熱灌流に際しては，低体温が必須である。 しかしながら， $30^{\circ} \mathrm{C}$ 以下の全身低体温は，エーテル麻 酔でない場合は心室細動の危険を有し，さらに血液凝 固能の上昇, 低カリウム血症, などが頻発する゙ため

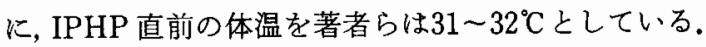
この場合の IPHPによる体温の上昇は，2 時間におい て 7 8 ${ }^{\circ} \mathrm{C}$ 以内であるので体温が $41^{\circ} \mathrm{C}$ 超党ることは なく，心肺機能に異常を来した症例はなかった。

温熱療法に制癌剤を加えることにより, 温熱と薬剤 の効果がより高まるが, 温熱により制癌効果の上昇が 顯著であり，かつ胃癌に対して広く感受性を持つもの としては, MMC, cis-dichlorodiammine platinum, 5-FUなどが挙げられる5). IPHP が術直後の 1 回のみ であり，灌流時間が限定されているので，短時間です 制癌作用の著しい濃度依存性薬剂である MMCを全 例に使用した，著者らの場合，灌流液内は低酸素状態 であり, MMC 濃度は平均 $3.3 \mu \mathrm{g} / \mathrm{ml}$ であるが, Teicher 56) は低酸素状態と好気性の場合は, 前者の方が 高温下の MMCの殺細胞作用がはるかに強いことを 報告している。

著者らの IPHP の灌流液の温度は既報の中では最 も高いが，それにもかかわらず腹膜再発を見ている。 蕰熱療法は DNA 合成期と細胞分裂期において制癌作 用が最も強く, MMC は $\mathrm{G}_{1}$ 後期より DNA 合成期にか けて強い作用を発揮する。腹腔内遊離細胞の細胞診断 は組織診断ではないので不確定の部分が残るが，マク ロファージ，中皮細胞が分裂増殖することは周知の事 実であり，残存癌細胞と推定した図 3 の細胞が，いわ ゆる反応性中皮細胞である可能性るある．体腔液中の 中皮細胞には静止期のものはなく，すべてが反応性中 皮細胞 (reactive mesothelial cell) であり, 欧米に拈 
図 6 Misonidazole (MIS)による thermosensitization $の$ 要約

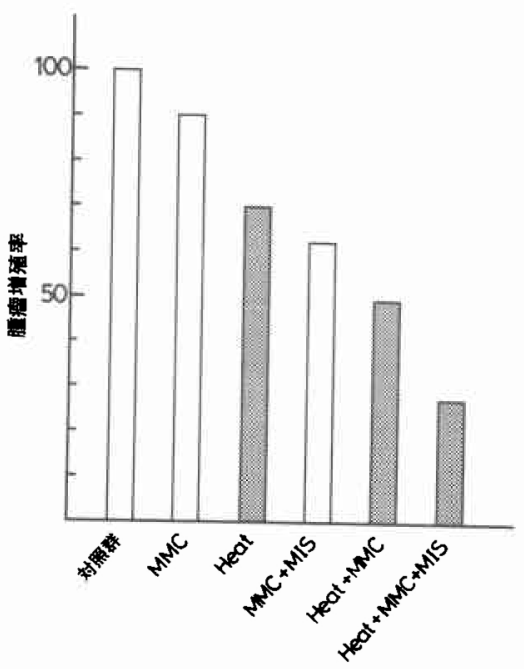

いてはこれを atypical mesothelial cell と表現するこ とが多く, 悪性細胞との鑑別が困難であることがある.

上述のように MMCを併用したIPHP療法の制癌 効果は強力であるが, 細胞周期依存性であるので, 理 論上癌細胞を零にすることはでさない，このため細胞 周期に依存しない制癌療法の併用が望ましく，著者ら は r IL-2 の局所療法を取り上げた。体腔内投与の場合 r IL-2 は局所に比較的長く留っているので, 末梢血中 $T$ 細胞, $N K$ 細胞の増殖促進は見られなかったが, 腹 腔内浸出液中の NK 細胞な明らかに増殖しており，局 所における殺細胞作用に大きな期待を寄せうるものと 考えられた。

MISの thermosensitization についてはたびたび報 告しているが277)819), その制癌性はMISの nitro 基が 還元されて nitro radical anion $\left(\mathrm{RNO}_{2}^{-}\right)$を経て hydroxyamine になるためであり27)8)，また腫瘍組織 内酸素分圧の低下と血液徽細循環の抑制促進, さらに は温熱耐性の発現の抑制など9)，その作用機作にはい まだ十分解明されていない面を蔵している、ヒト胃癌 細胞を使用しての MIS の温熱感受性促進作用（図 6) を要約すれば, 温熱に MMC+MISを併用することに よってそれぞれの制癌性の相加が認められてお

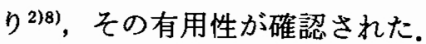

$$
\text { 結語 }
$$

漿膜露出胃癌18例に対して原発巣切除直後に，低体
温下において MMC $10 \mu \mathrm{g} / \mathrm{ml}$ を用いた腹腔内温熱灌 流を行い，以下の成績を得た。

1. 2 時間の温熱灌流中の灌流液内 $\mathrm{MMC}$ 濃度は平 均 $3.3 \mu \mathrm{g} / \mathrm{ml}$ であった。

2. 術中腹腔内洗浄液中の癌細胞陽性は14例 (77.8\%)であり，癌性腹水を認めた 6 例は術後に全例 腹水は消失した。

3. 術後 recombinant interleukin-2の腹腔内投与に より腹腔内浸出液中に $\mathrm{NK}$ 細胞の出現を認めた。

4. 腹腔内温熱灌流後に一過性の骨䯣抑制之肝障害 を認めた。

\section{文献}

1) Fujimoto $S$, Shrestha $R D$, Kokubun $M$ et al: Intraperitoneal hyperthermic perfusion combined with surgery effective for gastric cancer patients with peritoneal seeding. Ann Surg $208: 36-41,1988$

2) Fujimoto $S$, Ohta M, Shrestha RD et al: Enhancement of hyperthermochemotherapy for human gastric cancer in nude mice by thermosensitization with nitroimidazoles. $\mathrm{Br} \mathrm{J}$ Can. cer $57: 42-45,1988$

3) Dudar TE, Jain RK: Differential response of normal and tumor microcirculation to hyperthermia. Cancer Res $44: 605-612,1984$

4) Berne RM : Cardiodynamics and the coronary circulation in hypothermia. Ann NY Acad Sci $80: 365-383,1959$

5) Barlogie B, Corry PM, Drewinko B : In vitro thermochemotherapy of human colon cancer cells with cis-dichlorodiammineplatinum (II) and mitomycin C. Cancer Res $40: 1165-1168$, 1980

6) Teicher BA, Kowal CD, Kennedy $\mathrm{KA}$ et al : Enhancement by hyperthermia of the in vitro cytotoxicity of mitomycin $\mathrm{C}$ toward hypoxic tumor cells. Cancer Res $41: 1096-1099,1981$

7) 藤本茂, 太田正保, セレスタ $\mathrm{RD}$ ほ： Nitroimidazoleを使用したヒト胃癌腫湯に対す るChemosensitization 検討。癌の臨 34 ： $179-182,1988$

8）太田正保, 藤本 茂, セレスタ RDほか：低酸素性 放射線増感凧を併用した温熱化学療法の検討. 癌 の臨 $34: 283-287,1988$

9）国分和司, 藤本 茂, セレスタ RD ほ：温熱耐性 と畽湯組織内酸素濃度より見た Misonidazole 併 用温熱療法の検討。日外会誌 $89: 417,1988$ 